\title{
Criminal Convictions in Norwegian Female and Male Adult ADHD Outpatients: Prevalence and Associations With ADHD Symptom Severity and Emotional Dysregulation
}

\section{Espen ANKER ( $\nabla$ espen.anker@online.no )}

Locus Coeruleus https://orcid.org/0000-0003-4960-1715

\section{Ylva Ginsberg}

Kl: Karolinska Institutet

\section{Trond Heir}

University of Oslo: Universitetet i Oslo

\section{Research article}

Keywords: ADHD severity, offending, deficient emotional self-regulation, emotional dysregulation, criminal conviction, antisocial behaviour, substance use disorder

Posted Date: December 9th, 2020

DOl: https://doi.org/10.21203/rs.3.rs-122082/v1

License: (c) (1) This work is licensed under a Creative Commons Attribution 4.0 International License.

Read Full License 


\section{Abstract}

Objectives

Attention Deficit Hyperactivity Disorder (ADHD) often co-occurs with antisocial behaviour. Several studies have shown high rates of ADHD among prisoners. However, the prevalence of crime among individuals with ADHD is less known. The aim of the present study was to estimate the prevalence of lifetime criminal conviction (CC) in a clinical sample of adults with ADHD, and the associations with severity of ADHD and emotional dysregulation (ED).

\section{Methods}

Patients were admitted to a private psychiatric outpatient clinic in Oslo between 2014 and 2018. Out of 656 patients diagnosed with ADHD, 629 (95.9\%) agreed to participate in the study. CC was determined based on self-reporting of the lifetime history of criminal behaviour. ADHD was diagnosed according to DSM-5 criteria, and the ADHD severity was measured using the Adult ADHD Self Report Scale (ASRS). ED was assessed by the eight-item version of Barkley's Current Behaviour Scale - Self Report (CBS-SR).

Results

The prevalence of self-reported CC in this clinical sample was $11.7 \%$ among women and $24.5 \%$ among men. CC was associated with hyperactive-impulsive severity $(p<0.001)$ and $E D(p=0.006)$.

Conclusions

The prevalence of self-reported lifetime criminal conviction was high for both genders. CC was associated with symptom severity of hyperactivity-impulsivity and emotional dysregulation.

\section{Introduction}

Attention Deficit Hyperactivity Disorder (ADHD) often co-occurs with antisocial behaviour (Sourander et al. 2006; Mohr-Jensen \& Steinhausen. 2016). Several studies have estimated the prevalence of ADHD among male inmates to range between 15-50\% (Rösler et al. 2004; Einarsson et al 2009; Ginsberg et al. 2010; Usher et al, 2013; Knecht et al. 2015). Meta-analyses have indicated an average of around $25 \%$ in male inmates (Young et al. 2015; Baggio et al. 2018), and even as high as $40 \%$ in female inmates (Farooq et al. 2016). These rates far exceed the estimated 3-5\% prevalence rates of ADHD in the general adult population (Fayyad et al. 2007; Kessler et al. 2006).

Longitudinal studies find ADHD children to have a high risk of later antisocial activity and CC in adulthood (Fletcher \& Wolfe. 2009). Long-term outcome of Danish children with ADHD indicated that nearly half got a criminal conviction (CC) in adulthood (Dalsgaard et al. 2013). Others found girls with ADHD to have seven times higher odds for having an incarceration record compared to non-ADHD girls, while boys with ADHD had two times higher odds (Silva et al. 2014). A Swedish national register-based 
study found $15.4 \%$ of women and $36.6 \%$ of men with ADHD convicted of any crime (Lichtenstein et al. 2012). Several studies have indicated that $C C$ and antisocial behaviour are correlated with the severity of ADHD (Young \& Thome. 2011; Mohr-Jensen \& Steinhausen. 2016; Mordre et al 2011; Unnever \& Cornell. 2003; Du Rietz et al. 2017).

Previous studies have found general adjustment problems to be linked to antisocial behaviour in adults with ADHD (Young and Gudjonsson. 2006), and being largely mediated by emotional lability and anger problems (Gudjonsson et al. 2014). Excessive and inappropriate emotional expressions, irritability, and temper outbursts may be captured as the clinical expression of Emotional Dysregulation (ED) (Shaw et al. 2014; Stringaris. 2011). ED is a common feature in ADHD, even though it is not part of the criteria of the disorder (Aldao et al. 2016; Shaw et al. 2014; Connor et al. 2010; Landaas et al. 2012; Barkley et al. 2010; Barkley \& Fischer. 2010; Surman et al. 2011; Surman et al, 2013; Retz et al. 2012; Corbisiero et al. 2017; Hirsch et al. 2018).

ED in adults is clinically similar to conduct disorder in youth, which has been linked to antisocial behaviour (Mannuzza et al. 1989; Mannuzza et al. 2008; Satterfield et al. 2007; Mordre et al. 2011). Whether the severity of ED is associated with CC has yet to be shown.

The aims of the present study were to estimate the prevalence of CC in a clinical sample of outpatients with $A D H D$, and to examine its associations with ADHD symptom severity and ED.

\section{Methods}

This was an observational cross-sectional clinical study.

\section{Participants}

The study population consisted of adult outpatients, not imprisoned, aged 18 to 65 , who fulfilled the diagnostic criteria for a diagnosis of ADHD according to Diagnostic and Statistical Manual of Mental Disorders, Fifth Edition (DSM-5) (APA. 2013). Patients were admitted to a private outpatient non-inmate psychiatric clinic in Oslo, Norway, specialized in clinical assessment and treatment of adults with ADHD.

Recruitment was conducted between 2014 and 2018. ADHD was assessed using DIVA 2.0 the semistructured Diagnostic Interview for Adult ADHD, second edition (Kooij \& Francken 2010) which was performed by a psychiatrist for all patients included in the study. The DIVA 2.0 is a reliable tool for assessing and diagnosing Adult ADHD (Ramos-Quiroga. 2019). During these years, 656 of the assessed patients fulfilled the diagnostic criteria of ADHD and were invited to participate in the study, of whom $65 \%$ were self-referred and $35 \%$ were referred by healthcare practitioners. None of the participants used prescribed stimulant medication at the time of assessment. There were no exclusion criteria.

Out of 656 patients (351 men and 305 women) with ADHD, 629 (95.9\%) gave written informed consent to participate in the study. The study was approved by the Regional Medical Ethics Committee, South-East 
Norway, 2015/426. Assessments were carried out in accordance with ethical standards, and the principals of the Declaration of Helsinki.

\section{Measures}

The age of the participants was recorded as their respective numbers of lived years when entering the study. Gender was recorded as women (scored as 0 ) or men (scored as 1 ) from information revealed by the participant. Sociodemographic information: If participant was married or cohabitant this was scored as 1 , and if not scored as 0 . If participant was living with children, inclusive partial custody was scored as 1 , and if not (event though having children somewhere else) scored as 0 . Educational level was categorized by number of years in education; 12 years or less scored as 1, 13-15 years scored as 2 , or more than 15 years scored as 3 . Work participation was defined as 'yes' and scored as 1 if work was reported as the main source of income, and if not scored as 0 .

Criminal conviction (CC) was recorded as positive and scored as 1, when participant self-reported CC, and we recorded what they were convicted of. Absence of CC was scored as 0.

ADHD symptom severity was measured by Adult ADHD Self-Report Scale (ASRS) Symptom Check List, v1.1 (Adler, Kessler \& Spencer. 2003; Kessler et al. 2005; WHO 2007). The ASRS is a reliable and valid screening instrument for evaluating ADHD in adults (Silverstein et al. 2017). This 18-item version yields a score ranging from 0 to 72 points. We recorded subdivisions of the ASRS questionnaire, as inattentive items (item 1-4 and 7-11) and hyperactive - impulsivity items (item 5, 6, and 12-18) separately (Fredriksen et al. 2014).

ED was assessed by using the relevant eight items from Current Behaviour Scale - Self Report questionnaire (Barkley. 1997; Barkley et al. 2010; Surman et al. 2013; Biederman et al. 2012). The eight items were; 1: Quick to get angry or become upset; 2: Easily frustrated; 3: Overreact emotionally; 4: Easily excited by activities going on around me; 5: Lose my temper; 6: Argue with others; 7: Am touchy or easily annoyed by others; 8: Am angry or resentful. The items were by participant marked as never or rarely (0), sometimes (1), often (2) or very often (3). This yielded a total ED score ranging from 0 to 24.

Alcohol and drug use disorders were diagnosed using the specific module of the Mini International Neuropsychiatric Interview (M.I.N.I.), Norwegian Translation Version 6.0.0, according to the Diagnostic and Statistical Manual of Mental Disorders, Fourth Edition (DSM-IV) criteria. (Sheehan et al. 1997; Sheehan et al. 1998). Dependence and abuse were merged to "use" disorder (as in M.I.N.I. version 7.0 / DSM-5), and questions were both restricted to the last 12-months and related to lifetime prevalence.

Statistical analysis

Numbers with percent proportion (\%) were reported for all categorical variables. Means with standard deviations (SD) were given for continuous variables. We used chi-square $\left(\mathbb{\nabla}^{2}\right)$ tests to compare categorical variables and independent sample T-tests to compare continuous variables. We used logistic regression 
analyses to examine the associations between CC outcome variable, and age, gender, ADHD symptom severity and ED as independent variables. All tests were two-tailed, and differences were considered significant if $p<0.05$. There were no missing data. All statistical analyses were done using the software package IBM 2016 SPSS version 22 (IBM. 2016).

\section{Results}

Table 1 shows participants with and without a history of $\mathrm{CC}$. Those with a history of CC were older, more often men, had a lower educational level, were less involved in family life and work, and had a higher risk of a history of alcohol or drug use disorders.

The prevalence of CC was $11.7 \%(n=34)$ in women and $24.5 \%(n=83)$ in men.

Among women $(n=290)$, the most common conviction was for selling or possessing drugs $(n=18$; $6.2 \%)$, followed by violence, $(n=6 ; 2.1 \%)$, traffic crime $(n=6 ; 2.1 \%)$, theft $(n=2 ; 0.7 \%)$, and mixt or plural convictions $(n=2 ; 0.7 \%)$.

Among men ( $n=339)$, the most common conviction was for selling or possessing drugs $(n=32 ; 9.4 \%)$, followed by violence, $(n=24 ; 7.1 \%)$, traffic crime $(n=14 ; 4.1 \%)$, theft $(n=5 ; 1.5 \%)$, and mixt or plural convictions ( $n=8 ; 2.4 \%)$.

Hyperactive-impulsive symptoms and ED were higher in patients who had a history of CC (table 1). Table 2 shows that hyperactive-impulsive symptoms and ED were associated with CC even when adjusted for age and gender.

There were no significant interactions between age, gender, hyperactive-impulsive symptom severity and ED.

\section{Discussion}

Our results show that the prevalence of $\mathrm{CC}$ was high, and associated with both hyperactive-impulsive symptom severity and ED.

The $11.7 \%$ prevalence of CC among women and the $24.5 \%$ prevalence among men are slightly lower than what have been documented in a Swedish register-based study (Lichtenstein et al. 2012), and considerably lower than what was found in a follow-up study of Danish children (Dalsgaard et al. 2013). However, our estimates are much higher compared to the estimated lifetime prevalence of CC in the general Norwegian population, accumulated up to age 36 being $0.9 \%$ for women and $5 \%$ for men (Skardhamar. 2014). Our findings demonstrate that patients receiving an ADHD diagnosis in adulthood often also have a history of CC.

The two or threefold higher risk of CC among men versus women is in line with other studies of ADHD patients (Dalsgaard et al. 2013; Silva et al. 2014; Knecht et al. 2015). The ratio is similar to that in the 
general population (Skardhamar. 2014; Walker \& Maddan. 2016), which indicates that gender differences are not affected by ADHD.

The finding that $\mathrm{CC}$ was associated with the severity of hyperactive-impulsive symptoms is in line with several studies that have shown associations between the severity of ADHD symptoms and different aspects of antisocial behaviour (Gudjonsson et al. 2013; Gudjonsson et al. 2014; Gudjonsson et al. 2016; Gudjonsson et al. 2019; Gonzalez et al. 2016; Thapar et al. 2006; Storebø et al. 2016). It is also consistent with longitudinal studies of children with ADHD showing that the severity of hyperactivity-impulsivity symptoms was associated with later occurrence of CC (Dalsgaard et al. 2013; Pingault et al. 2013), It is likely that restlessness and impulsivity symptoms may result in less well-considered behavior that may also include violation of law. It is also possible that criminal acts by people with hyperactive-impulsive symptoms are more sensation and novelty seeking (Donfrancesco et al 2015, Mann et al 2017), and less planned and proactive, and that people with ADHD therefore are more likely being convicted (Young. 2007).

With this aspect in mind, it seems meaningful to address the severity of ADHD as emphasized in DSM-5, contrary to categorize ADHD by sub-types as suggested in DSM-IV. The strong association between CC and hyperactive-impulsive severity also underlines the importance of treating ADHD as a dimensional diagnosis and expecting more antisocial behavior in patients presenting with high levels of hyperactiveimpulsive symptoms.

In our sample, $C C$ was associated with the severity of $E D$, independent of the hyperactive-impulsive severity. We suggest that ED does add significantly to the understanding of $C C$ in people with ADHD.

Firstly, ED is a common feature of ADHD, even though not being part of the diagnostic criteria (Aldao et al. 2016; Shaw et al. 2014; Connor et al. 2010; Landaas et al. 2012; Barkley. 2010; Barkley \& Fischer. 2010; Surman et al. 2011; Surman et al. 2013; Retz et al. 2012; Corbisiero et al. 2017; Hirsch et al. 2018), Secondly, ED contributes significantly to the general impairments in patients with ADHD (Faraone et al 2018), and has an independent effect on general social problems associated with ADHD (Surman et al. 2013; Musser et al. 2013). Thirdly, aggression in childhood has been found to predict criminality later in life (Pingault et al. 2013), and personality traits of negative emotionality have been linked to criminal activity (Krueger et al. 1994).

We found a strong relationship between all background variables and $\mathrm{CC}$. The association between low education and CC is notable since people with ADHD have lower levels of education than the general population (Ebejer et al. 2012; Küpper et al. 2012; Barkley et al. 2006). Also, drug use disorder was correlated with CC, which is worth noting since ADHD patients have higher incidences of drug use (Gudjonsson et al. 2014; Dalsgaard et al. 2014; Von Polier et al. 2012; Crunelle et al. 2018; Anker et al. 2020). Early identification of ADHD and disruptive behaviour, with subsequent multimodal interventions might reduce the risk of a criminal trajectory. Supporting people with ADHD attaining higher education and avoiding drugs is probably also a good approach to prevent CC. 
There are some methodological limitations to consider in this study. CC was based on self-report which may have resulted in underreport.

Patients attended to a private and not governmentally funded clinic may not be representative for patients with ADHD in general. They may have a higher socio-economic status and be less impaired, compared to public outpatient clinics or prison inmates. Also, the prevalence rates of criminality and morbidity may not be representative for the total ADHD patient population. Since representativeness is time- and place-specific there will always be a historical concept (Olsen. 2013). We assume that differences in sample selection may primarily affect the prevalence rates, and to a lesser extent their associations (Nohr \& Olsen. 2013; Rothman et al. 2013). The associations with CC should therefore be more general.

The cross-sectional observational design limits the interpretation of causal relationships. We assume ADHD and ED are personality traits developing in childhood before criminal minimum age, which is 15 years of age in Norway, and therefore may indicate a direction of causality.

\section{Conclusion}

In this clinical sample the prevalence of self-reported lifetime criminal conviction (CC) was high for both genders compared to prevalence rates reported in the general population. CC was associated with the severity of hyperactivity and impulsivity, as well as emotional dysregulation, which indicate that both features contribute to the understanding of CC in ADHD.

\section{Clinical implication:}

Lifetime self-reported CC is common in adults with ADHD. Higher severity of hyperactivity-impulsivity symptoms and emotional dysregulation is associated with CC and should be treated with consciousness. There's a need for early identification and different approaches in prevention and treatment of ADHD and externalising behaviour. Further, targeted interventions should focus on the preventive effect of academic achievement and higher education for adolescents with ADHD, which could be crucial in order to avoid illegal drug use, antisocial behavior and delinquency.

\section{Abbreviations}

ADHD: Attention Deficit Hyperactivity Disorder

ED: Emotional Dysregulation

MINI: Mini International Neuropsychiatric Interview

ASRS: Adult ADHD Self Report Scale.

CC: Criminal conviction 


\section{Declarations}

We confirm that all methods were performed in accordance with relevant guidelines and regulations.

Ethics approval and consent to participate: The study was approved by the Regional Medical Ethics Committee, South-East D, Norway, 2015/426. Written consent to participate was obtained from all participants.

Consent for publication: Not applicable

Availability of data and materials: Data are collected from a private psychiatric outward in Oslo. Public availability would compromise privacy of the respondents. According to the approval from the Norwegian Regional committees for medical and health research ethics, the data have to be stored properly and in line with the Norwegian Law of privacy protection. However, anonymized data are freely available to interested researchers upon request, pending ethical approval from the ethics committee. Interested researchers can contact project leader Espen Anker (espen.anker@online.no) with requests for the data.

Competing interests: EA has received speaker honoraria from Shire. TH report no competing interest. YG has received personal fees and non-financial support from Medscape, non-financial support from Shire, and personal fees from Studentlitteratur, all outside the submitted work.

Funding: This work was economically supported by NevSom. Oslo University Hospital, grant number 51379. The funder had no other role in the study or writing the manuscript.

Authors' contributions: EA and TH designed the study. EA collected and analyzed the data. All the authors participated actively in the writing of the manuscript. All authors approved the final draft.

Acknowledgements: We want to thank Bothild Bendiksen, Susan Young and Gisli Gudjonsson for valuable input on the content.

\section{References}

Adler LA, Kessler RC \& Spencer T (2003). Adult ADHD self-report scale-v1. 1 (ASRS-v1. 1) symptom checklist. New York, NY: World Health Organization.

Anker E, Haavik J \& Heir T Alcohol and drug use disorders in adult attention-deficit/hyperactivity disorder: Prevalence and associations with attention-deficit/hyperactivity disorder symptom severity and emotional dysregulation. World J Psychiatr 2020; 10(9): 0000-0000 URL: https://www.wjgnet.com/ 22203206/full/v10/i9/0000.htm DOI: 10.5498/wjp.v10.i9.0000

APA, American Psychiatric Association. Diagnostic and statistical manual of mental disorders (DSM-5®). 2013: Pub. PMID: 8723190 DOI: 10.1176/appi.books.9780890425596.x00 
Baggio S, Fructuoso A, Guimaraes M, Fois E, Golay D, Heller P, ... \& Gétaz L (2018). Prevalence of attention deficit hyperactivity disorder in detention settings: a systematic review and meta-analysis. Frontiers in psychiatry, 9, 331. PMID: 30116206 DOI: 10.3389/fpsyt.2018.00331

Barkley RA. Behavioral inhibition, sustained attention, and executive functions: constructing a unifying theory of ADHD. Psychol Bull. 1997;121:65-94. PMID: 9000892 DOI: 10.1037/0033-2909.121.1.65

Barkley RA, Murphy KR, Robison RJ, Reimherr FW, Marchant BK, Kondo D, Coon H, Rosen PJ, Epstein JN. Deficient emotional self-regulation in adults with Attention deficit Hyperactive Disorder (ADHD): The Relative Contribution of Emotional Impulsiveness and ADHD symptoms to Adaptive Impairment in Major Life Activities. J ADHD Related Disorders 2010; 1: 5-28 [DOI: 10.1521/adhd.2010.18.4.1]

Barkley RA, Fischer A, Smallish L, Fletcher K. Young Adult Follow-Up of Hyperactive Children: Antisocial Activities and Drug Use. J Child Psychol Psychiatry. 2004 Feb;45(2): 195-211. PMID: 14982236 DOI: 10.1111/j.1469-7610.2004.00214.x

Barkley RA, Fischer M, Smallish L, Fletcher MAK. Young Adult Outcome of Hyperactive Children: Adaptive Functioning in Major Life Activities. J Am Acad Child Adolesc Psychiatry 2006 Feb; 45 (2):192-202. PMID 16429090 DOI: 10.1097/01.chi.0000189134.97436.e2

Barkley RA \& Fischer M (2010). The unique contribution of emotional impulsiveness to impairment in major life activities in hyperactive children as adults. Journal of the American Academy of Child \& Adolescent Psychiatry, 49(5), 503-513. PMID: 20431470 DOI: 10.1097/00004583-201005000-00011

Barkley RA, Murphy KR, Robison RJ, Reimherr FW, Marchant BK, Kondo D, Coon H, Rosen PJ \& Epstein JN (2010): Deficient emotional self-regulation in adults with Attention deficit Hyperactive Disorder (ADHD): The Relative Contribution of Emotional Impulsiveness and ADHD symptoms to Adaptive Impairment in Major Life Activities. J. ADHD Related Disorders (2010) vol 1, 5-28. DOI: 10.1521/adhd.2010.18.4.1

Biederman J, Spencer TJ, Petty C, Hyder LL, O'Connor KB, Surman CBH, Faraone SV. Longitudinal course of deficient emotional self-regulation $\mathrm{CBCL}$ profile in youth with ADHD: prospective controlled study. Neuropsychiatr Dis Treat. 2012; 8: 267-276. PMID: 22848182 DOI: 10.2147/NDT.S29670

Cappadocia MC, Desrocher M, Pepler D, \& Schroeder JH (2009). Contextualizing the neurobiology of conduct disorder in an emotion dysregulation framework. Clinical psychology review, 29(6), PMID: 19573964 DOI: 10.1016/j.cpr.2009.06.001

Cohen J. A power primer. Psychological bulletin. 1992 Jul;112(1):155. PMID: 19565683 DOI: 10.1037/0033-2909.112.1.155

Connor DF, Steeber J, McBurnett K. A review of attention- deficit/hyperactivity disorder complicated by symptoms of oppositional defiant disorder or conduct disorder. J Dev Behav Pediatr. 2010 Jun;31(5):42740. PMID: 20535081 DOI: 10.1097/DBP.0b013e3181e121bd 
Corbisiero S, Mörstedt B, Bitto H, Stieglitz RD. Emotional Dysregulation in Adults with AttentionDeficit/Hyperactivity Disorder-Validity, Predictability, Severity, and Comorbidity. J Clin Psychol. 2017 Jan;73(1):99-112. PMID: 27153511 DOI: 10.1002/jclp.22317

Crunelle CL, Van Den Brink W, Moggi F, Konstenius M, Franck J, Levin FR, Van De Glind G, Demetrovics Z, Coetzee $\mathrm{C}$, Luderer M, Schellekens A. International consensus statement on screening, diagnosis and treatment of substance use disorder patients with comorbid attention deficit/hyperactivity disorder. European addiction research. 2018;24(1):43-51. PMID: 29510390 DOI: 10.1159/000487767

Dalsgaard S, Mortensen PB, Frydenberg M, Thomsen PH, (2013) Long-term criminal outcome of children with attention deficit hyperactivity disorder. Criminal behavior and mental health, 10 April 2013 PMID: 23576439 DOI: $10.1002 / \mathrm{cbm} .1860$

Dalsgaard S, Mortensen PB, Frydenberg M, \& Thomsen PH (2014). ADHD, stimulant treatment in childhood and subsequent substance abuse in adulthood-a naturalistic long-term follow-up study. Addictive Behaviors, 39(1), 325-328. PMID: 24090624 DOI: 10.1016/j.addbeh.2013.09.002

DeLisi M, Drury AJ, \& Elbert MJ (2019). The etiology of antisocial personality disorder: The differential roles of adverse childhood experiences and childhood psychopathology. Comprehensive psychiatry, 92, 16. PMID: 31079021 DOI: 10.1016/j.comppsych.2019.04.001

Donfrancesco R, Di Trani M, Porfirio MC, Giana G, Miano S, \& Andriola E (2015). Might the temperament be a bias in clinical study on attention-deficit hyperactivity disorder (ADHD)?: Novelty Seeking dimension as a core feature of ADHD. Psychiatry research, 227(2-3), 333-338. PMID: 25895488 DOI:

10.1016/j.psychres.2015.02.014

Du Rietz E, Kuja-Halkola R, Brikell I, Jangmo A, Sariaslan A, Lichtenstein P, Kuntsi J, Larsson H. Predictive validity of parent-and self-rated ADHD symptoms in adolescence on adverse socioeconomic and health outcomes. European child \& adolescent psychiatry. 2017 Jul 1;26(7):857-67. PMID: 28185096 DOI: $10.1007 /$ s00787-017-0957-3

Ebejer JL, Medland SE, van der Werf J, Gondro C, Henders AK, Lynskey M, Martin NG, Duffy DL. Attention Deficit Hyperactivity Disorder in Australian Adults: Prevalence, Persistence, Conduct Problems and Disadvantage. Published: Plos one, October 10, 2012, Volume 7, Issue 10, e47404 PMID: 23071800 DOI: 10.1371/journal.pone.0047404

Erskine HE, Norman RE, Ferrari AJ, Chan GC, Copeland WE, Whiteford HA, \& Scott JG (2016). Long-term outcomes of attention-deficit/hyperactivity disorder and conduct disorder: a systematic review and metaanalysis. Journal of the American Academy of Child \& Adolescent Psychiatry, 2016;55(10), 841-850. PMID: 27663939 DOI: 10.1016/j.jaac.2016.06.016

Einarsson E, Sigurdsson JF, Gudjonsson GH, Newton AK, Bragason 0O. Screening for attention-deficit hyperactivity disorder and co-morbid mental disorders among prison inmates. Nord $\mathrm{J}$ 
Psychiatry. 2009;63(5):361-7. PMID: 19247871 DOI: 10.1080/08039480902759184

Faraone SV, Rostain AL, Blader J, Busch B, Childress AC, Connor DF, Newcorn JH. Practitioner Review: Emotional dysregulation in attention-deficit/hyperactivity disorder - implications for clinical recognition and intervention. J Child Psychol Psychiatry. 2018 Apr 6. PMID: 29624671 DOI: $10.1111 /$ jcpp. 12899

Farooq R, Emerson LM, Keoghan S, Adamou M. Prevalence of adult ADHD in an all-female prison unit. ADHD Attention Deficit and Hyperactivity Disorders. 2016 Jun 1;8(2):113-9. PMID: 26650925 DOI: $10.1007 / \mathrm{s} 12402-015-0186-\mathrm{x}$

Fayyad J. De Graaf R, Kessler R, Alonso J, Angermeyer M, Demyttenaere K, De Girolamo G, Haro JM, Karam EG, Lara C, Lépine JP, Ormel J, Posada-Villa J, Zaslavsky AM, Jin R., Cross-national prevalence and correlates of adult attention-deficit hyperactivity disorder. Br J Psychiatry, 2007. 190: p. 402-9. PMID: 17470954 DOI: 10.1192/bjp.bp.106.034389

Fazel S, Bains P, Doll H. Substance abuse and dependence in prisoners: a systematic review. Addiction. First published: 24 January 2006 PMID: 16445547 DOI: 10.1111/j.1360-0443.2006.01316.x

Fletcher J \& Wolfe B. Long-term Consequences of Childhood ADHD on Criminal Activities. J Ment Health Policy Econ. 2009 Sep; 12(3): 119-138. PMID: 19996475

Fredriksen M, Dahl AA, Martinsen EW, Klungsøyr O, Haavik J, Peleikis DE. Effectiveness of one-year pharmacological treatment of adult attention-deficit/hyperactivity disorder (ADHD): an open-label prospective study of time in treatment, dose, side-effects and comorbidity. Eur Neuropsychopharmacol 2014; 24: 1873-1884 [PMID: 25453480 DOI: 10.1016/j.euroneuro.2014.09.013]

Ginsberg Y, Hirvikoski T, Lindefors N. Attention Deficit Hyperactivity Disorder (ADHD) among longer-term prison inmates is a prevalent, persistent and disabling disorder.

BMC Psychiatry. 2010 Dec 22;10:112. PMID: 21176203 DOI: 10.1186/1471-244X-10-112

González RA, Gudjonsson GH, Wells J \& Young S. (2016). The role of emotional distress and ADHD on institutional behavioral disturbance and recidivism among offenders. Journal of Attention Disorders, 20, 368-78 PMID: 23893535 DOI: 10.1177/1087054713493322

Grieger $L$ and Hosser D.: Attention deficit hyperactive disorder does not predict criminal recidivism in young adult offenders: Results from a prospective study. International Journal of Law and Psychiatry 35 (2012) 27-34 PMID: 22142896 DOI: 10.1016/j.jilp.2011.11.005

Gudjonsson GH, Sigurdsson JF, Adalsteinsson TF \& Young S (2013). The relationship between ADHD symptoms, mood instability, and self-reported offending. Journal of attention disorders, 17(4), 339-346. PMID: 22290695 DOI: 10.1177/1087054711429791 
Gudjonsson GH, Sigurdsson JF, Sigfusdottir ID \& Young S (2014). A national epidemiological study of offending and its relationship with ADHD symptoms and associated risk factors. Journal of attention disorders, 18(1), 3-13. PMID: 22522573 DOI: 10.1177/1087054712437584

Gudjonsson GH, Sigurdsson JF, Sigfusdottir ID, Asgeirsdottir BB, González RA \& Young S (2016). A national epidemiological study investigating risk factors for police interrogation and false confession among juveniles and young persons. Social psychiatry and psychiatric epidemiology, 51(3), 359-367. PMID: 26537245 DOI: 10.1007/s00127-015-1145-8

Gudjonsson GH, Gonzalez R \& Young S (2019). The risk of making a false confession: The role of developmental disorders, conduct disorder, psychiatric symptoms, and compliance. Journal of Attention Disorders. PMID: 30895906 DOI: 10.1177/1087054719833169

Hirsch $\mathrm{O}$, Chavanon M, Reichmann E, Christiansen $\mathrm{H}$ : Emotional dysregulation is a primary symptom in adult Attention-Deficit / Hyperactivity Disorder (ADHD) Journal of Affective Disorders 232 (2018) 41-47 PMID: 29477097 DOI: 10.1016/j.jad.2018.02.007

IBM Corp. Released 2013. IBM SPSS Statistics for Windows, Version 22.0. Armonk, NY: IBM Corp. DOI: $10.4135 / 9781526435439$

Johnson P.: Educational attainment and crime. OUR PRISONERS, (2017) p77.

Kessler RC, Adler L, Ames M, Demler O, Faraone S, Hiripi EV, Howes MJ, Jin R, Secnik K, Spencer T, Ustun TB. The World Health Organization Adult ADHD Self-Report Scale (ASRS): a short screening scale for use in the general population. Psychological medicine. 2005; Feb;35(2):245-56. PMID: 15841682 DOI:

$10.1017 / \mathrm{s} 0033291704002892$

Kessler RC, Adler L, Barkley R, Biederman J, Conners CK, Demler O, Faraone SV, Greenhill LL, Howes MJ, Secnik K, Spencer T, Ustun TB, Walters EE, Zaslavsky AM., The prevalence and correlates of adult ADHD in the United States: results from the National Comorbidity Survey Replication. Am J Psychiatry, 2006. 163(4): p. 716-23. PMID: 16585449 DOI: 10.1176/ajp.2006.163.4.716

Knecht C, de Alvaro R, Martinez-Raga J and Balanza-Martinez V: Attention-deficit hyperactivity disorder (ADHD), substance use disorders, and criminality: a difficult problem with complex solutions Int $\mathrm{J}$ Adolesc Med Health 2015; 27(2): 163-175 PMID: 25411986 DOI: 10.1515/ijamh-2015-5007

Kooij JJS \& Francken MH (2010). Diagnostic interview for ADHD in adults 2.0 (DIVA 2.0). Adult ADHD: Diagnostic assessment and treatment, 33-99. PMID: DOI: 10.1007/978-1-4471-4138-9_3

Kolla NJ, Mark van der Maas, Patricia G. Erickson, Robert E. Mann, Jane Seeley, Evelyn Vingilis. Attention deficit hyperactivity disorder and arrest history: Differential association of clinical characteristics by sex. International Journal of Law and Psychiatry 58 (2018) 150-156 PMID: 29853005 DOI:

10.1016/j.ijlp.2018.04.006

Page $12 / 18$ 
Krueger RF, Schmutte PS, Caspi A, Moffitt TE, Campbell K, \& Silva PA (1994). Personality traits are linked to crime among men and women: evidence from a birth cohort. Journal of abnormal psychology, 103(2), 328. PMID: 8040502 DOI: 10.1037/0021-843X.103.2.328

Küpper T, Haavik J, Drexler H, Ramos-Quiroga JA, Wermelskirchen D, Prutz C, Schauble B. The negative impact of attention-deficit/hyperactivity disorder on occupational health in adults and adolescents. International Archives of Occupational and Environmental Health, November 2012, Volume 85, Issue 8, pp 837-847 PMID: 22752312 DOI: 10.1007/s00420-012-0794-0

Landaas ET, Halmøy A, Oedegaard KJ, Fasmer OB, Haavik J. The impact of cyclothymic temperament in adult ADHD. J Affect Disord. 2012 Dec 15;142(1-3):241-7. PMID: 22840630 DOI:

10.1016/j.jad.2012.04.034

Lichtenstein P, Halldner L, Zetterqvist J, Sjölander A, Serlachius E, Fazel S, ... \& Larsson H (2012). Medication for attention deficit-hyperactivity disorder and criminality. New England Journal of Medicine, 367(21), 2006-2014. PMID: 23171097 DOI: 10.1056/NEJMoa1203241

Lochner L. Education and crime. In The Economics of Education 2020 Jan 1 (pp. 109-117). Academic Press. DOI: 10.1016/B978-0-12-815391-8.00009-4

Mann FD, Engelhardt L, Briley DA, Grotzinger AD, Patterson MW, Tackett JL, ... \& Martin NG (2017). Sensation seeking and impulsive traits as personality endophenotypes for antisocial behavior: Evidence from two independent samples. Personality and individual differences, 105, 30-39. PMID: 28824215 https://doi.org/10.1016/j.paid.2016.09.018

Mannuzza S, Klein RG, Konig PH, Giampino TL. Hyperactive boys almost grown up: IV. Criminality and its relationship to psychiatric status. Archives of general psychiatry. 1989 Dec 1;46(12):1073-9. PMID: 2589922 DOI: 10.1001/archpsyc.1989.01810120015004

Mannuzza S. Klein RG. and Moulton III, JL (2008). Lifetime criminality among boys with attention deficit hyperactivity disorder: a prospective follow-up study into adulthood using official arrest records. Psychiatry research, 160(3), 237-246. PMID: 18707766 DOI: 10.1016/j.psychres.2007.11.003

Musser ED, Galloway-Long HS, Frick PJ, Nigg JT. Emotion regulation and heterogeneity in attentiondeficit/hyperactivity disorder. J Am Acad Child Adolesc Psychiatry. 2013 Feb;52(2):163-171.e2. PMID: 23357443 DOI: 10.1016/j.jaac.2012.11.009

Mohr-Jensen C \& Steinhausen H-C. A meta-analysis and systematic review of the risks associated with childhood attention-deficit hyperactivity disorder on long-term outcome of arrests, convictions, and incarcerations. Clinical Psychology Review 48 (2016) 32-42 PMID: 27390061 DOI:

10.1016/j.cpr.2016.05.002 
Mordre M, Groholt B, Kjelsberg E, Sandstad B and Myhre AM: The impact of ADHD and conduct disorder in childhood on adult delinquency: A 30 years follow-up study using official crime records. BMC Psychiatry (2011) 11:57 PMID: 21481227 DOI: 10.1186/1471-244X-11-57

Nohr EA, Olsen J Commentary: Epidemiologists have debated representativeness for more than 40 years -has the time come to move on? Int J Epidemiol 2013; 42 (4): 1016-1017 PMID: 24062289 DOI: $10.1093 /$ ije/dyt102

Olsen J. Random sampling-is it worth it? Paediatr Perinat Epidemiol 2013;27:27-28. PMID: 23215707 DOI: $10.1111 /$ ppe. 12020

Pingault J-B, Côté SM. Lacourse E. Galéra C, Vitaro F, Tremblay RE. Childhood Hyperactivity, Physical Aggression and Criminality: A 19-Year Prospective Population-Based Study. Published: PLOS May 1, 2013 Volume 8 | Issue 5 | e62594) PMID: 23658752 DOI: 10.1371/journal.pone.0062594

Ramos-Quiroga JA, Nasillo V, Richarte V, Corrales M, Palma F, Ibáñez P, ... \& Kooij JS (2019). Criteria and concurrent validity of DIVA 2.0: a semi-structured diagnostic interview for adult ADHD. Journal of attention disorders, 23(10), 1126-1135.

Retz W, Stieglitz RD, Corbisiero S, Retz-Junginger P and Rösler M.: Emotional dysregulation in adult ADHD: what is the empirical evidence? Expert Rev. Neurother. 12(10), 1241-1251 (2012) PMID: 23082740 DOI: $10.1586 /$ ern. 12.109

Rothman KJ, Gallacher JEJ, Hatch EE: Why representativeness should be avoided. International Journal of Epidemiology 2013;42:1012-1014 PMID: 24062287 DOI: 10.1093/ije/dys223

Rösler M, Retz W, Retz-Junginger P, Hengesch G, Schneider M, Supprian T, Schwitzgebel P, Pinhard K, DoviAkue N, Wender P, Thome J. Prevalence of attention deficit-/hyperactivity disorder (ADHD) and comorbid disorders in young male prison inmates. Eur Arch Psychiatry Clin Neurosci. 2004 Dec;254(6):365-71. PMID: 15538605 DOI: 10.1007/s00406-004-0516-z

Sourander A, Elonheimo H, Niemela S, Nuutila A-M, Helenius H, Sillanmaki L, Piha J, Tamminen T, Kumpulainen K, Moilanen I, AND Almqvist F. Childhood Predictors of Male Criminality: A Prospective Population-Based Follow-up Study From Age 8 to Late Adolescence. J. Am. Acad. Child Adolesc. Psychiatry, 2006;45(5):578Y586. PMID: 16670652 DOI: 10.1097/01.chi0000205699.58626.b5

Satterfield JH, Faller KJ, Crinella FM, Schell AM, Swanson JM, Homer LD. A 30-year prospective follow-up study of hyperactive boys with conduct problems: adult criminality. Journal of the American Academy of Child \& Adolescent Psychiatry. 2007 May 1;46(5):601-10. PMID: 17450051 DOI:

10.1097/chi.0b013e318033ff59

Shaw P. Stringaris A. Nigg J. Leibenluft E. Emotion dysregulation in attention deficit hyperactivity disorder. Am J Psychiatry, 2014. 171(3): p. 276-93. PMID: 24480998 DOI: 
Silva D, Colvin L, Glauert R \& Bower C (2014). Contact with the juvenile justice system in children treated with stimulant medication for attention deficit hyperactivity disorder: a population study. The Lancet Psychiatry, 1(4), 278-285.

Sheehan DV, Lecrubier Y, Sheehan KH, et al. The validity of the Mini International Neuropsychiatric Interview (MINI) according to the SCID-P and its reliability. Eur Psychiatry 1997;12:232-41. PMID: DOI: 10.1016/S0924-9338(97)83297-X

Sheehan DV, Lecrubier Y, Sheehan KH, et al. (1998). "The Mini-International Neuropsychiatric Interview (M.I.N.I.): the development and validation of a structured diagnostic psychiatric interview for DSM-IV and ICD-10". J Clin Psychiatry. 59 Suppl 20: 22-33. PMID: 9881538. DOI: 10.1037/t18597-000

Silverstein MJ, Alperin S, Faraone SV, Kessler RC, Adler LA. Test-retest reliability of the adult ADHD SelfReport Scale (ASRS) v1.1 Screener in non-ADHD controls from a primary care physician practice. Family Practice, 2017, cmx115. PMID: 29177453 DOI: 10.1093/fampra/cmx115

Skardhamar T: Lifetime conviction risk-a synthetic cohort approach, Journal of Scandinavian Studies in Criminology and Crime Prevention, 2014, 15:1, 96-101, DOI: 10.1080/14043858.2014.883175

Storebø OJ, Rasmussen PD, \& Simonsen E.: Association between insecure attachment and ADHD: environmental mediating factors. Journal of attention disorders, 2016. 20(2), 187-196. PMID: 24062279 DOI: $10.1177 / 1087054713501079$

Stringaris A: Irritability in children and adolescents: a challenge for the DSM 5. Eur Child Adolec Psychiatry 2011; 20: 61-66 PMID: 21298306 DOI: 10.1007/s00787-010-0150-4

Surman CB, Biederman J, Spencer T, Yorks D, Miller CA, Petty CR, Faraone SV. Deficient emotional selfregulation and adult attention deficit hyperactivity disorder: a family risk analysis. Am J Psychiatry, 2011. 168 (6): p. 617-23. PMID: 21498464 DOI: 10.1176/appi.ajp.2010.10081172

Surman CB, Biederman J, Spencer T, Miller CA, McDermott KM, Faraone SV. Understanding deficient emotional self-regulation in adults with attention deficit hyperactivity disorder: a controlled study. Atten Defic Hyperact Disord. 2013 Sep;5(3):273-81. PMID: 23413201 DOI: 10.1007/s12402-012-0100-8

Thapar A. van den Bree M. Fowler T. Langley K. Whittinger N. Predictors of antisocial behavior in children with attention deficit hyperactivity disorder Eur Child Adolesc Psychiatry (2006) 15:118-125 PMID: 16523253 DOI: 10.1007/s00787-006-0511-1

Unnever JD \& Cornell DG. Bullying, self-control, and ADHD. Journal of interpersonal violence. 2003 Feb;18(2):129-47. PMID: 22973420 DOI: 10.1177/0886260502238731 
Usher AM, Stewart LA, Wilton G. Attention deficit hyperactivity disorder in a Canadian prison population. International Journal of Law and Psychiatry. Volume 36, Issues 3-4, May-August 2013, Pages 311-315 PMID: 23639768 DOI: 10.1016/j.ijlp.2013.04.005

Von Polier GG, Vloet TD, Herpertz-Dahlmann B. ADHD and delinquency - a developmental perspective. Behav Sci Law 2012;30:121-39. PMID: 22371085 DOI: 10.1002/bsl.2005

Walker JT \& Maddan S (2016). Understanding Statistics for the Social Sciences, Criminal Justice, and Criminology. Jones \& Bartlett Publishers. p. 99. ISBN 1449634036. Retrieved August 7, 2016.

Watts SJ. ADHD Symptomatology and Criminal Behavior During Adolescence: Exploring the Mediating Role of School Factors. International Journal of Offender Therapy and Comparative Criminology 2018, Vol. 62(1) 3-23 PMID: 27056790 https://doi.org/10.1177/0306624X16639970

Young S (2007). Forensic aspects of ADHD. Handbook of attention deficit hyperactivity disorder, Fitzgerald M, Bellgrove M, Gill M (Eds). Wiley, Chichester, UK, 91-108

Young S \& Gudjonsson GH. ADHD symptomatology and its relationship with emotional, social and delinquency problems. Psychology, Crime \& Law. 2006 Oct 1;12(5):463-71. DOI:

$10.1080 / 10683160500151183$

Young S \& Thome J. ADHD and offenders. World J Biol Psychiatry 2011;12(Suppl 1):124-8. PMID: 21906010 DOI: $10.3109 / 15622975.2011 .600319$

Young S, Moss D, Sedgwick O, Fridman M, Hodgkins P. A meta-analysis of the prevalence of attention deficit hyperactivity disorder in incarcerated populations. Psychol Med. (2015) Jan;45(2):247-58. PMID: 25066071 DOI: $10.1017 /$ S0033291714000762

Young S, Wells J \& GH Gudjonsson. Predictors of offending among prisoners: the role of attention-deficit hyperactivity disorder and substance use. Journal of Psychopharmacology 25(11) 1524-1532 (2011) PMID: 20558498 DOI: 10.1177/0269881110370502

\section{Tables}

Tables 1. Demographics and clinical features in a sample of adult ADHD patients with and without a history of criminal conviction. Participants were recruited in an outpatient psychiatric clinic specialized in examination and treatment of ADHD. 


\begin{tabular}{|c|c|c|c|c|}
\hline & $\begin{array}{l}\text { Total } \\
\text { sample } \\
n=629\end{array}$ & $\begin{array}{l}\text { Criminal Conviction } \\
n=117\end{array}$ & $\begin{array}{l}\text { No-Criminal } \\
\text { Conviction } \\
\mathrm{n}=512\end{array}$ & $\begin{array}{l}\mathrm{p}- \\
\text { value }\end{array}$ \\
\hline Age, mean yrs. (SD) & $\begin{array}{l}36.7 \\
(11.4)\end{array}$ & $39.8(10.0)$ & $35.9(11.6)$ & 0.020 \\
\hline Gender: Women, n (\%) & $290(46.1)$ & $34(29.1)$ & $256(50.0)$ & $<0.001$ \\
\hline Men, n (\%) & $339(53.9)$ & $83(70.9)$ & $256(50.0)$ & \\
\hline Years of education: $\leq 12$ : $(\%)$ & $321(51.0)$ & $92(78.6)$ & $229(44.7)$ & $<0.001$ \\
\hline 13-15: (\%) & $248(39.4)$ & $24(20.5)$ & $224(43.8)$ & \\
\hline >15: (\%) & $60(9.5)$ & $1(0.9)$ & $59(11.5)$ & \\
\hline Married or cohabitant, n (\%) & $270(42.9)$ & $38(32.5)$ & $232(45.3)$ & 0.014 \\
\hline Living with children, n (\%) & $248(39.4)$ & $30(25.6)$ & $218(42.8)$ & 0.003 \\
\hline Work participation, n (\%) & $370(58.8)$ & $49(41.9)$ & $321(62.7)$ & $<0.001$ \\
\hline $\begin{array}{l}\text { Alcohol use disorder lifetime, } \\
\mathrm{n}(\%)\end{array}$ & $73(11.6)$ & $29(24.8)$ & $44(8.6)$ & $<0.001$ \\
\hline $\begin{array}{l}\text { Drug use disorder lifetime, } \mathrm{n} \\
(\%)\end{array}$ & $165(26.2)$ & $81(69.2)$ & $84(16.4)$ & $<0.001$ \\
\hline Inattentiveness, mean (SD) & $27.4(4.7)$ & $27.9(5.1)$ & $27.3(4.6)$ & 0.036 \\
\hline $\begin{array}{l}\text { Hyperactivity-Impulsivity, } \\
\text { mean (SD) }\end{array}$ & $23.9(6.6)$ & $26.7(5.8)$ & $23.3(6.6)$ & $<0.001$ \\
\hline $\begin{array}{l}\text { Emotional Dysregulation, } \\
\text { mean (SD) }\end{array}$ & $12.1(5.6)$ & $14.0(5.6)$ & $11.8(5.5)$ & $<0.001$ \\
\hline
\end{tabular}

P-values are due to comparison of ADHD patients with and without a history of criminal conviction (chisquare or t-test).

Table 2. Associations between ADHD symptom severity and emotional dysregulation as independent variables and criminal conviction as the outcome measure in a clinical sample of 629 adults with ADHD who were admitted to a psychiatric clinic specialized in examination of ADHD 


\begin{tabular}{|lllllll|}
\hline & \multicolumn{4}{l}{ Unadjusted } & \multicolumn{4}{l|}{ Adjusted } \\
& OR & $95 \% \mathrm{Cl}$ & $\mathrm{p}$-value & OR & $95 \% \mathrm{Cl}$ & p-value \\
\hline Age (increase in 10 years) & 1.34 & $1.13-1.60$ & 0.001 & 1.32 & $1.10-1.59$ & 0.003 \\
\hline Gender (Men v. Women) & 2.44 & $1.58-.77$ & $<0.001$ & 3.38 & $2.12-5.39$ & $<0.001$ \\
\hline $\begin{array}{c}\text { ADHD symptom severity } \\
\text { Inattentiveness }\end{array}$ & 1.03 & $0.98-1.07$ & 0.28 & 0.96 & $0.91-1.02$ & 0.17 \\
Hyperactivity-Impulsivity & 1.09 & $1.05-1.12$ & $<0.001$ & 1.09 & $1.04-1.13$ & $<0.001$ \\
\hline Emotional dysregulation & 1.08 & $1.04-1.12$ & $<0.001$ & 1.07 & $1.02-1.12$ & 0.006 \\
\hline
\end{tabular}

